\title{
The relationship between preoperative postoperative serum albumin levels and endometrial cancer prognostic factors
}

\section{Ameliyat öncesi ve ameliyat sonrası serum albumin düzeyinin endometrium kanseri prognostik faktörleri ile ilişkisi}

${ }^{1}$ Irem Alyazici Kucukyildiz, ${ }^{2}$ Unsal Guldemir, ${ }^{1}$ Begüm Kurt, ${ }^{3}$ Tahsin Takcı, ${ }^{1}$ Ali Yanık

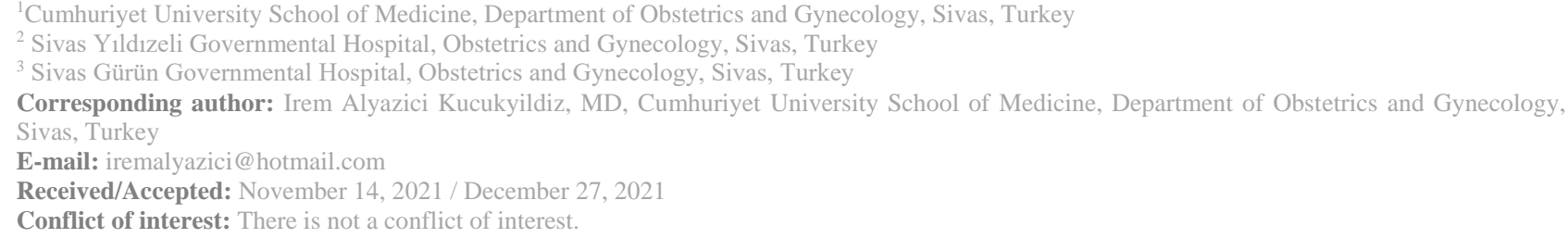

\section{SUMMARY}

Objective: Hypoalbuminemia is an accepted prognostic indicator of increased morbidity and mortality; however, low serum albumin levels during the pre-treatment period are associated with poor survival in cancer patients. This study aimed to investigate the effects of pre- and postoperative albumin levels on endometrial cancer (EC) prognosis and patient survival.

Method: Clinical and laboratory data for 128 patients with EC were obtained retrospectively from the hospital archive. Pre- and post-operative serum albumin levels were compared with patients' pathology results and survival.

Results: The mean age of the patients was 59.1 years, and $80.5 \%$ of patients had endometrioid type, $59.1 \%$ had grade 1 and $71.1 \%$ had stage I EC. The mean pre-operative albumin value of patients was $4.1 \mathrm{~g} / \mathrm{dL}$, and the mean post-operative albumin value of patients on post-operative day 1 was 3.39 $\mathrm{g} / \mathrm{dL}$. Both preoperative and postoperative albumin levels were found to be low in patients with have non-endometrioid type histology and advanced stage, which are considered as a poor prognostic factor in EC. While no correlation was found between the preoperative albumin level and overall survival, patients with a low postoperative albumin value showed poor survival.

Conclusions: The fact that serum albumin levels are associated with endometrial cancer prognostic factors suggests that albumin level may also be an independent prognostic factor, however prospective randomized studies are needed to make definite judgments on this issue.

Keywords: Endometrial cancer, serum albumin, prognosis, survival.

(I) Irem Alyazici Kucukyildiz
(D) Unsal Guldemir
(D) Begüm Kurt
(D) Tahsin Takcı
(D) Ali Yanık

ORCID IDs of the authors:

I.A.K. 0000-0002-6604-0713

U.G. 0000-0002-2799-6114

B.K. 0000-0002-7166-3130

T.T. 0000-0003-1709-1597

A.Y. 0000-0001-9634-2117 
Amaç: Serum albümin düşüklüğü, morbidite ve mortalitenin prognostik bir göstergesi olabilmekle birlikte, kanser hastalarında tedavi öncesi dönemde düşük serum albümin seviyeleri, daha kısa yaşam süresi ile de ilişkilendirilmiştir. Bu çalışmada, endometrium kanserli hastalarda (EC) ameliyat öncesi ve sonrası albümin düzeylerinin prognoz ve hastaların sağ kalımı üzerindeki etkileri araştıııldı.

Yöntem: 128 EC hastasının klinik ve laboratuvar verileri hastane arşivinden retrospektif olarak elde edildi. Ameliyat öncesi ve sonrası serum albümin düzeyleri, hastaların patoloji sonuçları ve sağ kalımları ile karşılaştıııldı.

Bulgular: Çalışmamızdaki hastaların ortalama yaşı 59.1 idi ve hastaların \% 80.5 inde endometrioid tip,\% 59.1'inde grade 1 ve \% 71.1'inde evre $1 \mathrm{EC}$ vardı. Ortalama ameliyat öncesi albümin değeri $4.1 \mathrm{~g} / \mathrm{dL}$ ve ortalama ameliyat sonrası 1. günde albümin değeri $3.39 \mathrm{~g} / \mathrm{dL}$ idi. Grade 2-3, evre II-IV ve endometrioid olmayan tip EC hastalarda postoperatif albümin düzeyi endometrioid tip, erken evre ve düşük gradeli hastalara göre anlamlı derecede düşük bulundu. Endometrioid tip dışı EC ve evre II- IV hastalarda ise preoperatif albümin düzeyi anlamlı olarak düşük bulundu. Ayrıca, postoperatif albümin değeri düşük olan hastalarda daha düşük sağkalım saptandı.

Sonuç: Serum albümin düzeylerinin endometrium kanseri prognostik faktörleri ile ilişkili olması, albümin düzeyinin de bağımsız bir prognostik faktör olabileceğini düşündürmekle birlikte, bu konuda kesin yargıya varmak için prospektif randomize çalışmalara ihtiyaç vardır.

Anahtar sözcükler: Endometrium kanseri, serum albümin, prognoz, sağkalım.

\section{INTRODUCTION}

Endometrial cancer (EC) is the second most common gynecological cancer in women, with around 380,000 new cases reported globally each year ${ }^{1}$, and generally has a good prognosis if diagnosed early. ECs are typically diagnosed by endometrial biopsy or dilatation and curettage in patients who presents with abnormal uterine bleeding and post-menopausal bleeding. EC is surgically staged and includes total hysterectomy, bilateral salpingo-oophorectomy and lymphadenectomy.

Many studies have reported histological type, grade, tumor size and stage as prognostic factors for $\mathrm{EC}^{2,3}$. On the other hand, various parameters, including hemoglobin, total protein, albumin and transferrin, are used to evaluate the nutritional status in patients with gynecological cancers ${ }^{4}$. Among these, albumin is one of the most investigated serum markers.

Albumin is an important serum protein that is synthesized by the liver and is predominantly responsible for the regulation of blood osmotic pressure and the transport of free radicals ${ }^{5}$. The rate of albumin synthesis is associated with nutrition and is affected by conditions such as malignancy, surgery and liver and kidney diseases 6,7. Albumin level is an accepted parameter to evaluate malnutrition. Serum albumin level, which can also be used as an indicator of mortality and morbidity in many chronic diseases, has been shown to be associated with survival in breast, gastric and lung cancers ${ }^{8-10}$.

Although the number of studies into gynecological cancers is limited, it is predicted that pre-operative serum albumin levels may be an independent risk factor for gynecological cancers.

In this study, aimed to determine the relationship between preoperative-postoperative serum albumin level and tumor grade, stage, histological type and survival in patients with EC that underwent surgery.

\section{MATERIAL AND METHODS}

This was retrospective non-randomized singlecenter study. Clinical and laboratory data were obtained retrospectively from the hospital archive. A total of 128 patients with EC that underwent surgery between 2009 and 2019 were included in the study. Endometrial biopsy results for all patients were examined. Patients with coexisting malignancies or synchronous cancers were excluded from the analysis.

Pathology results of the patients as well as routine pre- and post-operative blood test results were examined. Serum albumin levels were classified as either low $(<3.5 \mathrm{~g} / \mathrm{dL})$ or normal $(3.5-5 \mathrm{~g} / \mathrm{dL})$. EC histologic types and grades were evaluated according to the pathology results using the International Federation of Gynecologists and Obstetricians system for disease staging (I, II, III or IV).

Statistical evaluation of the data obtained in our study was performed using SPSS version 22 software. For the evaluation of the albumin values, normality was evaluated using the Shapiro-Wilk Test. Mann-Whitney $U$ test and Independent Samples T test were used to test the significance of the difference between pairs. Wilcoxon Signed Rank test was used to compare the laboratory findings both before and after surgery. Overall survival (OS) was defined as the time from the date 
of surgery to the date of death. Mantel-Cox method was used to estimate survival curves, and differences in survival were analyzed using the logrank test. Differences were considered statistically significant at a $\mathrm{p}$ value $<0.05$. P-values $<0.05$ were considered significant.

\section{RESULTS}

Data for 128 patients with EC who underwent surgery at the same centre and by the same surgical team between December 2009 and September 2019 were evaluated retrospectively.

The mean age of the patients was 59.1 [26-85] years. Total abdominal hysterectomy and bilateral salpingo-oophorectomy were performed on all patients, and 116 patients underwent pelvic ( \pm para-aortic) lymph node dissection. Evaluation of the patients' pathology results revealed that 103 patients $(80.5 \%)$ had endometriod type EC, 75 (59.1\%) patients had grade 1 and 91 had stage I (71.1\%) disease (Table 1).

Table 1: Patients' characteristics

\begin{tabular}{|c|c|c|}
\multicolumn{1}{c}{ Parameter } & \multicolumn{1}{c|}{$\%$} \\
\hline Histological subtype & & \\
Endometrioid histology & 103 & 80.5 \\
Non-Endometrioid histology & 25 & 19.5 \\
\hline Histological grade & & \\
Grade 1 & 75 & 59.1 \\
Grade 2 & 18 & 14.1 \\
Grade 3 & 34 & 26.8 \\
\hline Tumor stage & & \\
FIGO I & 91 & 71.1 \\
FIGO II & 14 & 10.9 \\
FIGO III & 13 & 10.2 \\
FIGO IV & 10 & 7.8 \\
\hline Preoperative albumin level & & \\
Low & 16 & 12.5 \\
Normal & 112 & 87.5 \\
\hline Pow & 70 & 54.7 \\
Normal & 58 & 45.3 \\
\hline Status & & \\
Alive & 109 & 85.2 \\
Dead & 19 & 14.8 \\
\hline
\end{tabular}

FIGO: International Federation of Gynecologists and Obstetricians system

The mean pre-operative albumin value of patients was $4.1(-(2.44-5) \mathrm{g} / \mathrm{dL}$, whereas the mean postoperative albumin value of patients evaluated on post-operative day 1 was $3.39(2.05-4.72) \mathrm{g} / \mathrm{dL}$.

A significant decrease was observed in albumin value on post-operative day 1 compared with the pre-operative albumin values (p: 0.001). However, no difference in postoperative albumin value was calculated between the groups with and without lymph node dissection ( $\mathrm{p}: 0.288$ ). In addition, as the age increased, both preoperative and postoperative albumin values were found to be lower.

The median preoperative albumin value was 4.23 , and the mean postoperative albumin value was 3,47 for endometrioid type EC patients. The median preoperative albumin value was 3.92 and the mean postoperative albumin value was 3,08 for nonendometrioid type EC patients (Table 2). When the preoperative albumin values of the patients with endometrioid type EC and non-endometrioid type EC were compared, a statistically significantly lower albumin level was found in the patients with non-endometrioid type EC (p:0.01) (Table2). When the postoperative albumin levels of the patients with endometrioid type EC and nonendometrioid type EC were compared, a statistically significantly lower albumin level was found in the patients with non-endometrioid type EC $(\mathrm{p}<0,001)($ Table2) 
There was no statistically significant relationship between pre-operative albumin value and tumor grade, but there was a relationship between postoperative albumin value and tumor grade. When the postoperative albumin levels of patients with grade 1 and grade $\geq 2$ tumor were compared, a statistically significantly lower albumin level was found in the patients with grade $\geq 2$ tumor $(\mathrm{p}<0,001)$ (Table 2)

Table 2: Comparison of albumin values (preoperative and postoperative) with endometrial cancer prognostic factors

\begin{tabular}{|c|c|c|c|c|c|c|c|c|c|c|}
\hline \multicolumn{2}{|l|}{ Parameters } & \multicolumn{4}{|c|}{ Preoperative albumin value } & \multicolumn{4}{|c|}{ Postoperative albumin value } & \multirow[b]{2}{*}{$\mathrm{p}^{* * *}$} \\
\hline & & Per. 25 & Per.75 & Median & IQR & Min. & Max. & Mean & Std. Dev. & \\
\hline \multirow[t]{2}{*}{ Stage } & FIGO stage I & 4,00 & 4,57 & 4,24 & 0,57 & 2,10 & 4,72 & 3,46 & 0,46 & $<0,001$ \\
\hline & FIGO Stage II, III, IV & 3,59 & 4,33 & 4,00 & 0,74 & 2,05 & 4,53 & 3,24 & 0,54 & $<0,001$ \\
\hline & & \multicolumn{4}{|c|}{$p^{*}: 0,009$} & \multicolumn{4}{|c|}{$p^{* *}: \mathbf{0 , 0 2 5}$} & \\
\hline \multirow[t]{2}{*}{ Grade } & grade 1 & 4,00 & 4,50 & 4,24 & 0,50 & 2,60 & 4,72 & 3,53 & 0,45 & $<0,001$ \\
\hline & grade 2 and 3 & 3,68 & 4,38 & 4,10 & 0,70 & 2,05 & 4,41 & 3,20 & 0,48 & $<0,001$ \\
\hline & & \multicolumn{4}{|c|}{ p*: 0,06} & \multicolumn{4}{|c|}{$\mathbf{p}^{* *}:<0,001$} & \\
\hline \multirow[t]{2}{*}{ Histological type } & endometrioid type & 4,00 & 4,54 & 4,23 & 0,54 & 2,60 & 4,72 & 3,47 & 0,45 & $<0,001$ \\
\hline & non-endometrioid type & 3,57 & 4,23 & 3,92 & 0,66 & 2,05 & 4,41 & 3,08 & 0,52 & $<0,001$ \\
\hline & & \multicolumn{4}{|c|}{$p^{*}: 0,01$} & \multicolumn{4}{|c|}{$\mathrm{p}^{* * *}:<0,001$} & \\
\hline
\end{tabular}

Per.25:Percentile 25, Per.75: Percentile 75, IQR: Interquartile Range, Min: Minimum, Max: Maximum,

Std.Dev.:Standar Deviation

p*: Mann-Whitney U test was performed, $p>0.05$ was considered significant

$\mathrm{p}^{* *}$ : Independent Sample T test was performed, $\mathrm{p}>0.05$ was considered significant

$\mathrm{p}^{* * *}$ : Wilcoxon Rank Test was performed, $\mathrm{p}>0.05$ was considered significant

In addition, both preoperative and postoperative albumin levels were statistically significantly lower in the patients with stage 2 and above. (p: 0,009; p:0.025) (Table 2)

When the patients with pelvic and para-aortic lymph node involvement were evaluated separately, the postoperative albumin value was found to be statistically significant lower in the patients with para-aortic lymph node involvement (p:0.003)

When the preoperative albumin levels (lownormal) of the patients were compared with the survival, no statistically significant difference was found between the groups (p:0.898). (Figure 1).
When the albumin levels were evaluated as low $(<3.5 \mathrm{~g} / \mathrm{dL})$ or normal $(3.5-5 \mathrm{~g} / \mathrm{dL})$ during the postoperative period, the overall survival of the patients with low post-operative albumin values was $77 \pm$ 6.2 months $(95 \%$ confidence interval $[\mathrm{CI}]=65-89$ months). The overall survival of the patients with normal post-operative albumin values was $86 \pm 3$ months (95\% CI $=80-92$ months). The overall survival for all patients was $87 \pm 3.8$ months $(95 \%$ $\mathrm{CI}=79.5-94.7$ months). This difference was significant when both groups were compared (p:0.012) (Figure 2). 


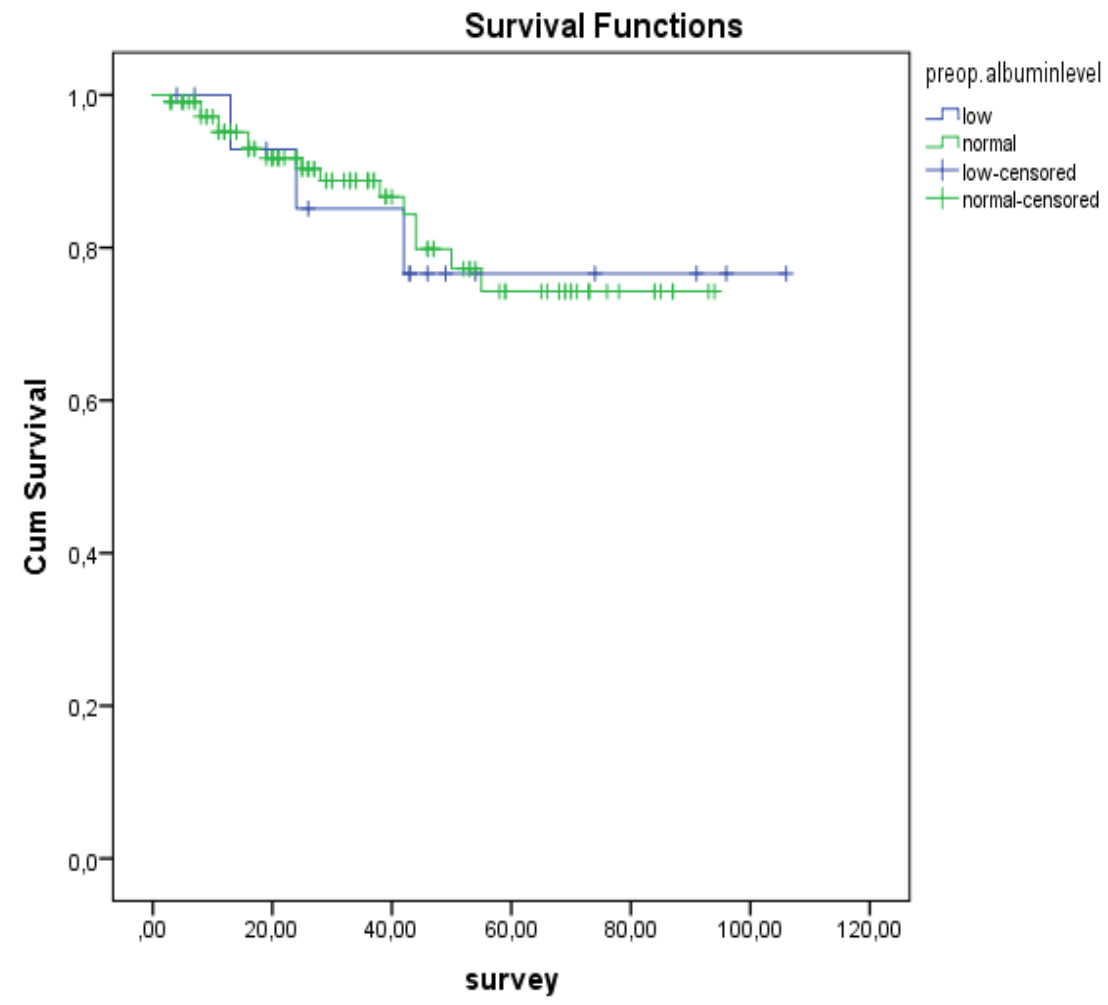

Figure 1: Graphical Presentation of Montel-Cox Analyses of Preoperative Albumin Level and Overall Survival (p:0.898)

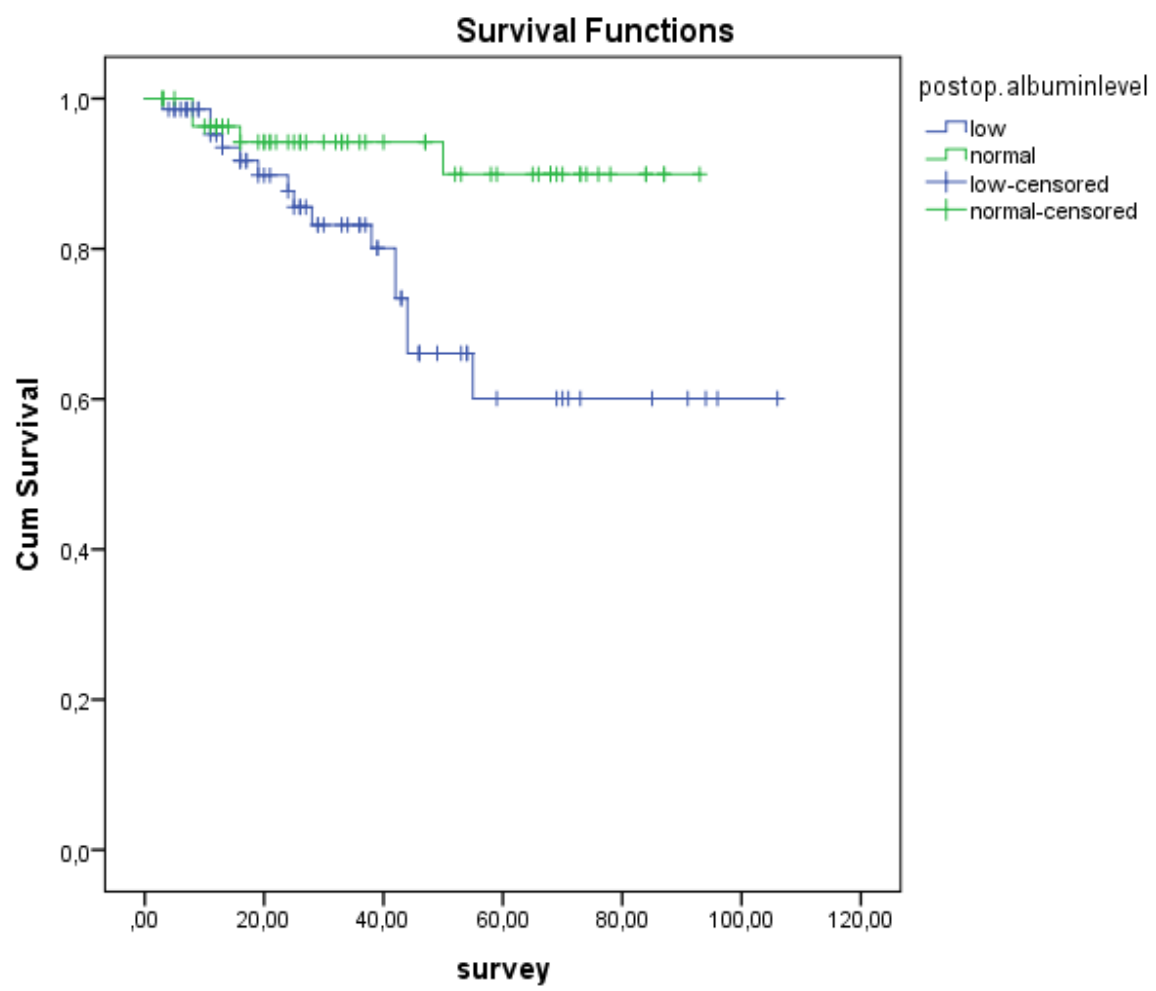

Figure 2: Graphical Presentation of Montel-Cox Analyses of Postoperative Albumin Level and Overall Survival (p:0.012) 


\section{DISCUSSION}

The overall survival of patients with EC, which is the most common gynecological cancer developed countries, is $>80 \%$ when all stages are included. However, when histological types are evaluated separately, the prognosis of type $1 \mathrm{EC}$, which is usually hormone sensitive and seen in the postmenopausal period, is good if caught at an early stage ${ }^{11}$.

The recently reported opinion that nutrition has an impact on cancer survival has become widespread. Serum albumin levels are considered important indicators of malnutrition, and values before treatment were found to be effective in survival for many cancers ${ }^{12}$.

The normal serum albumin range is defined as 3.5$5.0 \mathrm{~g} / \mathrm{dL}$, and levels $<3.5 \mathrm{~g} / \mathrm{dL}$ are considered hypoalbuminemia in the adult population ${ }^{13,14}$. Malnutrition and inflammation suppress albumin synthesis ${ }^{15}$, and cancer patients frequently have lower albumin levels, especially in advanced stages. In advanced stage cancers, the tumor burden is high and malnutrition is accompanied by weight loss. Low levels of serum albumin are associated with poor survival in cancer patients ${ }^{12}$.

Among gynecological cancers, the prognostic effect of albumin has been most frequently questioned in ovarian cancer, and low levels of albumin prior to treatment in ovarian cancers were associated with poor survival ${ }^{12,16,17}$.

A study on 337 patients with EC revealed a relationship between pre-treatment albumin values and disease-free and progression-free survival, and reported that serum albumin value could be shown as a new prognostic parameter for survival in patients with endometrial cancer ${ }^{18}$. At the same time, pretreatment albumin level was compared with tumor characteristics in this study. Tumor stage, grade and patient age were inversely proportional to albumin levels.

In a study evaluating the preoperative albumin levels of 345 patients with EC cancer, it was found that patients with older age, G1-G2 histological grade and FIGO stage I-II, without lymph node metastasis had worse overall survival when preoperative serum albumin levels were at a low level ${ }^{19}$.

There are very limited studies in the literature examining serum albumin levels and endometrial cancer prognosis. Our study also found results consistent with this limited number of studies. Moreover, both preoperative albumin levels and postoperative albumin levels were evaluated in this study. In our study, serum albumin levels were found to be associated with tumor histological type, tumor grade and stage, which are prognostic factors for endometrial cancer. Low albumin level was significantly associated with non-endometrioid histology, high grade and advanced stage. In addition, EC patients with normal postoperative albumin levels were found to have significantly longer overall survival than those with low albumin values, although there was no significant association between preoperative albumin level and overall survival. We predict that especially low postoperative albumin level may be important in terms of survival and poor prognosis for endometrial cancer.

In the patients undergoing cancer surgery, prolonged surgery, lymph node dissection and postoperative lymphorrea may have an effect on low postoperative albumin levels. On the other hand, factors such as blood transfusion or albumin replacement may affect the postoperative albumin level. In this study, no significant correlation was found between performing lymph node dissection and postoperative albumin values. The low number of patients who did not undergo lymph node dissection may be the reason for this.

Deficiencies in patient data (especially postoperative blood, fresh frozen plasma transfusion), which are typical features of retrospective studies, and statistical limitations due to low mortality rates due to generally good prognosis-early stage in EC can be stated as the weaknesses of our study.

\section{CONCLUSION}

Although it is supported by the data of our study that serum albumin level is associated with EC prognostic factors, there is a need for prospective randomize studies including intraoperativepostoperative data for the underlying mechanisms of changing serum albumin levels in EC patients.

Conflict of interest: The authors declare that they have no competing interest.

Financial Disclosure: There are no financial supports.

Ethical approval: All procedures performed in this study were in accordance with the ethical standards of the institutional research committee and with the 1964 Helsinki Declaration and its later amendments or comparable ethical standards. Human Research Ethics Committee of the Sivas 
Cumhuriyet University approval was received for this study [registry no: 2020-03/36]. Informed consent was not obtained from the participants included in this study because of the retrospective nature of the study.

\section{REFERENCES}

1. Bray F, Ferlay J, Soerjomataram I, Siegel RL, Torre LA, Jemal A. Global cancer statistics 2018: GLOBOCAN estimates of incidence and mortality worldwide for 36 cancers in 185 countries. CA Cancer J Clin. 2018 ;68(6):394-424

2. Kosary, CL. FIGO stage, histology, histologic grade, age and race as prognostic factors in determining survival for cancers of the female gynecological system: an analysis of 1973-87 SEER cases of cancers of the endometrium, cervix, ovary, vulva, and vagina. In Seminars in surgical oncology. New York: John Wiley \& Sons, Inc; 1994:31-46.

3. Schink JC, Miller DS, Lurain JR, Rademaker AW. Tumor size in endometrial cancer. Cancer. 1991 1;67(11):2791-4cncr2820671113>3.0.co;2-s

4. Laky B, Janda M, Bauer J, Vavra C, Cleghorn G, Obermair A. Malnutrition among gynaecological cancer patients Eur J Clin Nutr. 2007;61(5):642-6.

5. Margarson MP, Soni N. Serum albumin: touchstone or totem? Anaesthesia. 1998;53(8):789803.

6. Nicholson JP, Wolmarans MR, Park GR. The role of albumin in critical illness. $\mathrm{Br} \mathrm{J}$ Anaesth. 2000;85(4):599-610.

7. Al-Shaiba R, McMillan DC, Angerson WJ, Leen E, McArdle CS, Horgan P. The relationship between hypoalbuminaemia, tumour volume and the systemic inflammatory response in patients with colorectal liver metastases. Br J Cancer. 2004 19;91(2):205-7

8. Al Murri AM, Bartlett JM, Canney PA, Doughty JC, Wilson C, McMillan DC. Evaluation of an inflammation-based prognostic score (GPS) in patients with metastatic breast cancer. Br J Cancer. 2006 30;94(2):227-30.

9. Lien YC, Hsieh CC, Wu YC, Hsu HS, Hsu WH, Wang LS, et al. Preoperative serum albumin level is a prognostic indicator for adenocarcinoma of the gastric cardia. J Gastrointest Surg. 2004 ;8(8):1041-8

10. Fiala O, Pesek M, Finek J, Racek J, Minarik M, Benesova L, et al. Serum albumin is a strong predictor of survival in patients with advancedstage non-small cell lung cancer treated with erlotinib. Neoplasma. 2016;63(3):471-6.

11. Amant F, Moerman P, Neven P, Timmerman D, Van Limbergen E, Vergote I. Endometrial cancer. Lancet 2005 ;366:491-505.

12. Gupta D, Lis CG. Pretreatment serum albumin as a predictor of cancer survival: a systematic review of the epidemiological literature. Nutr J. 2010 22;9:69

13. Di Fiore F, Lecleire S, Pop D, Rigal O, Hamidou $\mathrm{H}$, Paillot $\mathrm{B}$, et al. Baseline nutritional status is predictive of response to treatment and survival in patients treated by definitive chemoradiotherapy for a locally advanced esophageal cancer. Am J Gastroenterol. 2007;102(11):2557-63.

14. Ishizuka M, Nagata $H$, Takagi $K$, Horie $T$, Kubota $\mathrm{K}$. Inflammation-based prognostic score is a novel predictor of postoperative outcome in patients with colorectal cancer. Ann Surg. 2007;246(6):1047-51

15. Yeun JY, Kaysen GA. Factors influencing serum albumin in dialysis patients. Am J Kidney Dis. 1998 ;32(6 Suppl 4):S118-25.

16. Ayhan A, Günakan E, Alyazıcı İ, Haberal N, Altundağ Ö, Dursun P. The preoperative albumin level is an independent prognostic factor for optimally debulked epithelial ovarian cancer. Arch Gynecol Obstet. 2017 ;296(5):989-995.

17. Asher V, Lee J, Bali A. Preoperative serum albumin is an independent prognostic predictor of survival in ovarian cancer. Med Oncol. 2012;29(3):2005-9.

18. Seebacher V, Grimm C, Reinthaller A, Heinze G, Tempfer C, Hefler L, et al. The value of serum albumin as a novel independent marker for prognosis in patients with endometrial cancer. Eur J Obstet Gynecol Reprod Biol. 2013;171(1):101-6.

19. Lei J, Wang Y, Guo X, Yan S, Ma D, Wang P, et al. Low preoperative serum ALB level is independently associated with poor overall survival in endometrial cancer patients. Future Oncol. 2020;16(8):307-316. 